\title{
Commentary
}

\section{Why you should have a Perfusionist as Workforce in the Intensive Care Unit}

\author{
Gabriele Melegari ${ }^{1, *},(0)$, Maria Chiara Franchini ${ }^{2}$, Francesca Sola ${ }^{2}$, Emanuela Testa ${ }^{3}$, Alberto Barbieri ${ }^{4}$ \\ ${ }^{1}$ Department of Anaesthesia and Intensive Care, Azienda Ospedaliero-Universitaria di Modena, Via del Pozzo 71, Modena 41121, Italy \\ ${ }^{2}$ Aferetica Srl, Bologna, Italy \\ ${ }^{3}$ Cardiosurgery Unit, Cà Foncello Hospital, Azienda ULSS 2 Treviso, Italy \\ ${ }^{4}$ School of Anaesthesia and Intensive Care, University of Modena and Reggio Emilia, Italy
}

\author{
ARTICLE INFO \\ Article History \\ Received 07 July 2021 \\ Accepted 26 August 2021

\section{Keywords} \\ Perfusionist \\ ECMO \\ training
}

() 2021 First Affiliated Hospital of Zhengzhou University. Publishing services by Atlantis Press International B.V. This is an open access article distributed under the CC BY-NC 4.0 license (http://creativecommons.org/licenses/by-nc/4.0/).
In 2018 the Italian government founded the College of Perfusionists, regulating this profession. Since 1982 the perfusionist had a training education of 2 years at the Faculty of Medicine, initially as a cardiopulmonary technician in cardiac surgery. Then in 1998, this course was increased to 3 years to develop a specific team-mate dedicated both to Cardiology and Cardio-surgery Unit (CSU). This health care workforce in Italy usually works in the Cath-Lab, in Cardiology, Coronary Unit, or Cardio-surgery but, despite this type of worker could have some potential skills, especially in the modern general Intensive Care Unit (ICU) he is not still present in these settings as it should be [1]. The perfusionist should be helpful and necessary as a residential unit in the ICU, supporting the physicians in many critical care settings. The perfusionist-course includes specific training in several settings such as Echocardiography (ECHO) Lab, Cath-lab, CSU, Cardio-Vascular Unit. During the course, the students can learn, not only perfusion, ECHO and electrophysiology, but also Extracorporeal Membrane Oxygenation (ECMO) and Continuous Renal Replacement Therapy (CRRT) (Table 1). The clinical competences of the perfusionist are functional to the continuous evolution of treatments and monitoring in the ICU. In this setting, it is always more common monitoring the cardiac output and hemodynamic parameters using the ECHO assessment, with trans-thorax evaluation, instead of the Swan Ganz catheter or PICCO ${ }^{\circledR}$ Pulsion System (Getinge, Sweden), reducing the risk of many complications [2]. ECMO procedure is not so common and easy to apply in all ICUs because generally it is feasible only in selected hospitals with a CSU, where the perfusionist is on board and on call $24 \mathrm{~h}$ a day. In this last period, this technique

"Corresponding author. Email: melegari.gabriele@gmail.com

Peer review under responsibility of the First Affiliated Hospital of Zhengzhou University had become an effective strategy to gain time to recover the respiratory function in case of acute respiratory distress syndrome, in case of severe Covid-19 pneumonia or, for H1N1 flu disease [3]. Furthermore, extracorporeal circulation such as CRRT or ECMO may benefit from hemoadsorption filter [4,5]. The increasing need for organ donation has focused on investigating the use of ECMO in case of the Donation after Circulatory Death. This procedure tries to save and restore organs from cadaver immediately after a refractory cardiac arrest. The use of ECMO in this last case is functional to restore organs circulation [6]. For this reason, the presence of a perfusionist should help to use this device in many settings and help the physician and nurse team for the cardiological assessment and in many daily activities. There are few papers or clinical trials regarding the presence of perfusionists in ICU; at the same time, there are trials regarding the benefit of ECMO performed by a perfusionist [7]. In Italy the $63.7 \%$ of perfusionists, find a job after graduation in less than 3 months, the $91.9 \%$ with a private employ, only the $6.5 \%$ in public health and finally only $1.6 \%$ works for non-profit organization [8]. According to unpublished data of the Italian College of Perfusionists, at the moment there are seven hospitals where there are 17 perfusionists working for ECMO in ICUs or performing ECHO. The majority of these hospitals do not have a CSU. In three hub hospitals in Italy with $\mathrm{CSU}$, one perfusionist is present $24 \mathrm{~h}$ /day for ECMO procedures, and in the other hospitals, he is on call during the nights and festive days. Anyway the importance of multidisciplinary equipe in ICU is well known. Multidisciplinary teamwork in ICU has many positive effects, increasing skills and knowledge of all ICU medical-nurse teams, improving the quality of care, probably with a better allocation of resources [9]. Despite this, this concept is still not common in Italy. It might be helpful and necessary an extended fellowship 
Table 1 Clinical training and targets during the Graduation of Perfusionist

\begin{tabular}{|c|c|c|}
\hline Clinical trainings & Targets & Degree year \\
\hline $\begin{array}{r}\text { Echocardiography and } \\
\text { Holter reading clinic }\end{array}$ & $\begin{array}{l}\text { ECG track execution and its } \\
\text { interpretation }\end{array}$ & $\begin{array}{l}\text { I and II } \\
\text { Year }\end{array}$ \\
\hline Haemodialysis & $\begin{array}{l}\text { Preparation, setup, and operation } \\
\text { of the hemodialysis machine }\end{array}$ & II Year \\
\hline $\begin{array}{l}\text { Echocardiography } \\
\text { clinic }\end{array}$ & $\begin{array}{l}\text { Technical execution of the complete } \\
\text { quantitative assessment exam }\end{array}$ & II Year \\
\hline $\begin{array}{l}\text { Respiratory function } \\
\text { clinic }\end{array}$ & $\begin{array}{l}\text { Tests to evaluate cardio-respiratory } \\
\text { function }\end{array}$ & II Year \\
\hline Vascular ultrasound & $\begin{array}{l}\text { Flowmeter evaluations of the } \\
\text { vascular system }\end{array}$ & II Year \\
\hline $\begin{array}{l}\text { Hemodynamic and } \\
\text { electrophysiology }\end{array}$ & $\begin{array}{l}\text { Preparation, management, and } \\
\text { application of the equipment }\end{array}$ & $\begin{array}{l}\text { II and III } \\
\text { Year }\end{array}$ \\
\hline $\begin{array}{l}\text { Cardio-surgery and } \\
\text { ECMO }\end{array}$ & $\begin{array}{l}\text { Preparation, management, and } \\
\text { application of the equipment } \\
\text { Management and application of } \\
\text { extracorporeal circuits }\end{array}$ & III Year \\
\hline Intensive care unit & $\begin{array}{l}\text { Management of extracorporeal } \\
\text { devices, echocardiography, and } \\
\text { electrocardiography }\end{array}$ & III Year \\
\hline
\end{tabular}

in the ICU at the end of the degree course. Furthermore, recording in an electronic log-book all skills and training and maneuvers performed by perfusionist students, as it happens for a resident of the School of Anaesthesia and Intensive Care, could favorite their integration in the ICU team [10]. The perfusionist could be an added value to the medical-nurse team, in the modern ICU.

\section{CONFLICTS OF INTEREST}

The authors declare they have no conflicts of interest.

\section{AUTHORS' CONTRIBUTION}

All authors equally contributed to this paper: Gabriele Melegari writing. Maria Chiara Franchini and Francesca Sola concept of idea. Emanuela Testa and Alberto Barbieri reviewed the paper.

\section{FUNDING}

No financial support was provided.

\section{REFERENCES}

[1] Belway D, Rubens FD, Tran DTT. Practice meta-environment of the cardiovascular perfusionist. Perfusion 2018;33;83-4.

[2] Hahn RT, Abraham T, Adams MS, Bruce CJ, Glas KE, Lang RM, et al. Guidelines for performing a comprehensive transesophageal echocardiographic examination: recommendations from the American Society of Echocardiography and the Society of Cardiovascular Anesthesiologists. J Am Soc Echocardiogr 2013;26;921-64.

[3] Cho HJ, Heinsar S, Jeong IS, Shekar K, Li Bassi G, Jung JS, et al. ECMO use in COVID-19: lessons from past respiratory virus outbreaks-a narrative review. Crit Care 2020;24;301.

[4] Melegari G, Bertellini E, Melegari A, Trenti T, Malaguti S, Barbieri A. Hemoadsorption cartridge and coronavirus disease 2019 infections: a case report and brief literature review. Artif Organs 2021;45;E130-E5.

[5] Alharthy A, Faqihi F, Memish ZA, Balhamar A, Nasim N, Shahzad A, et al. Continuous renal replacement therapy with the addition of CytoSorb cartridge in critically ill patients with COVID-19 plus acute kidney injury: a case-series. Artif Organs 2021;45;E101-E12.

[6] Baroni S, Melegari G, Brugioni L, Gualdi E, Barbieri A, Bertellini E. First experiences of hemoadsorption in donation after circulatory death. Clin Transplant 2020;34;e13874.

[7] Agati S, Ciccarello G, Trimarchi ES, Grasso D, Trimarchi G, Di Stefano S, et al. Extracorporeal circulation, optimized: a pilot study. Artif Organs 2007;31;377-83.

[8] Cerca professioni. Available from: https://www2.almalaurea.it/ cgi-asp/professioni/ (accessed August 16, 2021).

[9] Donovan AL, Aldrich JM, Gross AK, Barchas DM, Thornton KC, Schell-Chaple HM, et al. Interprofessional care and teamwork in the ICU. Crit Care Med 2018;46;980-90.

[10] Barbieri A, Melegari G, Giuliani E. Could an electronic logbook be effective for medical training in anaesthesiology?. Eur J Anaesthesiol 2020;37;515. 